\title{
PENERAPAN METODE LEAST SQUARE UNTUK PREDIKSI PENJUALAN BERBASIS WEB PADA DONI SPORT MALANG
}

\author{
Ahmad Ridwan $^{1}$, Ahmad Faisol ${ }^{2}$, Febriana Santi Wahyuni ${ }^{3}$ \\ Program Studi Teknik Informatika S1, Fakultas Teknologi Industri \\ Institut Teknologi Nasional Malang, Jalan Raya Karanglo km 2 Malang, Indonesia \\ ridean97@gmail.com
}

\begin{abstract}
ABSTRAK
Dalam penjualan tentunya diperlukan pendataan untuk mengontrol pendapatan pertahunnya, dan pendataan yang ada saat ini masih dilakukan secara manual, sehingga akan menghabiskan waktu yang cukup lama, dan informasi mengenai stok dan penjualannya pun mengalami tumpang tindih, sehingga kesulitan untuk mencarinya, dan pemilik toko juga pun tidak mengetahui pendapatan bulan ini lebih meningkat atau menurun. Prediksi ini bertujuan untuk mengetahui jumlah barang yang akan disediakan pada bulan selanjutnya pada Doni Sport Malang yang bertempat di Jalan Sawahan, ngijo, Karangploso, Malang.

Dari permasalahan tersebut, digunakanlah metode Least Square untuk prediksi penjualan pada Doni Sport Malang dengan masa periode setiap bulan dari tahun 2017 sampai 2019. Metode peramalan (forecasting) kuadrat terkecil atau yang biasa disebut sebagai metode least square adalah metode peramalan yang menggunakan persamaan linear untuk menemukan garis paling sesuai untuk kumpulan data lampau guna meramalkan data di masa depan. (Noegroho Boedijoewono, 2007:231).

Berdasarkan pengujian Black Box fungsional sitem dapat berjalan sesuai desain perancangan, dan berdasarkan pengujian data penjulan sepatu Adidas Predator pada januari-desember 2017 mendapatkan hasil 145unit dan memiliki selisih 20unit dari data asli januari 2018.
\end{abstract}

Kata kunci : Least Square, data mining, prediksi penjualan

\section{PENDAHULUAN}

Doni Sport Malang berdiri pada tahun 2011 merupakan toko yang menyediakan berbagai macam kebutuhan yang berhubungan dengan alat olah raga, khususnya sepatu futsal dan sepatu sepak bola. Dalam penjualan tersebut tentunya diperlukan pendataan untuk mengontrol pendapatan pertahunnya, dan pendataan yang ada saat ini masih dilakukan secara manual, sehingga akan menghabiskan waktu yang cukup lama, dan informasi mengenai stok dan penjualannya pun mengalami tumpang tindih, sehingga kesulitan untuk mencarinya, dan pemilik toko juga pun tidak mengetahui pendapatan bulan ini lebih meningkat atau menurun.

Peramalan (Bahasa Inggris $=$ Forecasting) adalah suatu teknik analisa perhitungan yang dilakukan dengan pendekatan kualitatif maupun kuantitatif untuk memperkirakan kejadian dimasa depan dengan menggunakan referensi data-data di masa lalu. Peramalan bertujuan untuk memperkirakan prospek ekonomi dan kegiatan usaha serta pengaruh lingkungan terhadap prospek tersebut. Peramalan atau Forecasting merupakan bagian terpenting bagi setiap perusahaan ataupun organisasi bisnis dalam setiap pengambilan keputusan manajemen. Peramalan itu sendiri bisa menjadi dasar bagi perencanaan jangka pendek, menengah maupun jangka panjang suatu perusahaan. Di dalam sebuah peramalan (forecasting) dibutuhkan sedikit mungkin kesalahan (error) di dalamnya. Agar dapat meminimalisir tingkat kesalahan tersebut, maka akan lebih baik jika peramalan tersebut dilakukan dalam satuan angka atau kuantitatif.

Menurut Rahmawati dalam penelitian yang berjudul "Forcasting Penjualan Sepeda Motor Kawasaki Pada PT. Sumber Buana Motor Yogyakarta tahun 2013 ", Rahmawati mengungkapkan semakin tahun semakin berkembang namun kadang juga berkurangnya produksi sepeda motor dipasaran tentunya. Produksi memperhatikan permintaan pasar, untuk mengetahui permintaan pasar suatu perusahaan melakukan forcasting penjualan yaitu dapat divcari menggunakan Tren untuk memperkirakan berapa jumlah penjualan yang mungkin terjadi ditahun yang akan datang. Metode yang digunakan yaitu Metode Least suare. Hasil yang didapat yaitu dapat mengetahui bagaimana permintaan pasar dan managemen penjualan yang akan datang pada tahun berikutnya, dengan demikian perusahaan akan mendapatkan banyak keuntungan karena sudah mengetahui perkiraan penjualan yang akan datang. Jadi metode Least Square sangat membantu suatu Prediksi kebutuhan pasar yang akan datang. [1]

Dari permasalahan tersebut, digunakanlah metode Least Square untuk prediksi penjualan pada Doni Sport Malang dengan masa periode setiap bulan dari tahun 2017 sampai 2019. 


\section{TINJAUAN PUSTAKA}

\subsection{Penelitian Terkait Prediksi Penjualan}

Natalia melakukan analisis peramalan penjualan dan pengendalian persediaan di PT. Bentaro. Naatalia mengungkapkan bahwa PT.Bentaro merupakan perusahaan yang bergerak dibidang distributor Ice Cream Wall's yang belum memiliki system untuk mengendalikan persediaan yang optimal. Jadi diperlukan sebuah peramalan untuk mengetahui prediksi persediaan yang akan datang paada bulan berikutnya. Peramalan terseut menggunakan metode forcesting dan material requirements. Yang dihasilkan yaitu dapat mengendalikan persediaan pada bulan berikutnya sehingga perusahaan tidak mendaptkan kerugian atau meminimalisir kerugian. [2]

Iskandar Selanjutnya melakukan penelitian peramalan penjualan produk kripik pisang. Iskandar mengungkapkan bahwa suatu perusahaan yang bergerak dibidang jasa penjualan atau pendistributor selalu menginginkan keberhasilan dalam aktivitasnya dimana pada waktu yang akan datang. Hal ini menunjukkan bahwa setiap perusahaan selalu berusaha untuk tetap berkembang pada waktu yang akan datang. Untuk mewujudkan hal tersebut digunakan sebuah metode Single moving Average. Hasil yang didapatkan yaitu perusahaan dapat memproduksi kripik pisang dengan stok yang dibutuhkan sesuai dengan permintaan, dan perusahaan akan merasa aman karena minimnya kerugian yang akan didapatnya. [3]

Firnando melakukan penelitian tentang analisis peramalan penjualan Buncis Super. Fernando mengungkapkan bahawa Buncis di Indonesia ini memiliki potensi ekonomi yang sangat baik. Sebab peluang pasarnya cukup luas yaitu untuk sasaran pasar luar Negeri. Akan tetapi, penjualan buncis dipasar kota pekan baru mengalami permasalahan yaitu jumlah permintaan buncis yang selalu beruahubah tidak menentu. Maka dari itu dilakukan suatu peramalan untuk menentukan banyaknya permintaan pasar. Dengan begitu maka tingkat keuntungan juga akan meningkat sehingga tidak ada yang dirugikan. peramalan yang akan diterapkan yaitu menggunakan metode trend analysis. Metode ini nantinya yang akan menentukan berapa banyaknya permintaan pada waktu yang akan datang. [4]

\subsection{Data mining}

Data mining adalah suatu proses ekstraksi atau penggalian data dan informasi yang besar, yang belum diketahui sebelumnya, namun dapat dipahami dan berguna dari database yang besar serta digunakan untuk membuat suatu keputusanbisnis yang sangat penting. Data mining menggambarkan sebuah pengumpulan teknik-teknik dengan tujuan untuk menemukan pola-pola yang tidak diketahui pada data yang telah dikumpulkan. Data mining memungkinkan pemakai menemukan pengetahuan dalam data database yang tidak mungkin diketahui keberadaanya oleh pemakai. Teknik data mining digunakan untuk memeriksa basis data berukuran besar sebagai cara untuk menemukan pola yang baru dan berguna.

Secara khusus, data mining menggunakan ideide seperti (1) pengambilan contoh, estimasi, dan pengujian hipotesis, dari statistika dan (2) algoritme pencarian, teknik pemodelan, dan teori pembelajaran dari kecerdasan buatan, pengenalan pola, dan machine learning. Data mining juga telah mengadopsi ide- ide dari area lain meliputi optimisasi, evolutionary computing, teori informasi, pemrosesan sinyal, visualisasi dan information retrieval. Sejumlah area lain juga memberikan peran pendukung dalam data mining, seperti sistem basis data yang dibutuhkan untuk menyediakan tempat penyimpanan yang efisien,

\subsection{Least Square}

Metode peramalan kuadrat terkecil atau yang biasa disebut sebagai metode least square adalah metode peramalan yang menggunakan persamaan linear untuk menemukan garis paling sesuai untuk kumpulan data lama guna untuk mengetahui data yang akan datang.

Bentuk Persamaan Tren Tren penjualan adalah suatu garis naik atau turun yang menunjukkan tingkat penjualan. Persamaan tren dapat mempunyai berbagai bentuk, yaitu:

Bentuk persamaan garis lurus dirumuskan:

$\mathrm{Y}^{\prime}=\mathrm{a}+\mathrm{bX}$

$Y^{\prime}=$ Nilai variabel dependen

$\mathrm{X}=$ Nilai variabel independen dalam analisis tren (waktu)

$\mathrm{a}=$ Intercept $\mathrm{Y}$, yakni nilai $\mathrm{Y}$ apabila $\mathrm{X}=0$

$\mathrm{b}=$ Lereng garis tren

Persamaan ini menunjukkan garis lurus atau linier.

Perhitungan Metode Least Square

Menentukan nilai keseimbangan $\mathrm{X}$

Perhitungan $X^{2}$

Perhitungan XY

Mencari nilai a

Mencari nilai b

Perhitungan Persamaan Tren

I. $\quad \sum \mathrm{Y}=\mathrm{Na}+\mathrm{b} \sum \mathrm{X}$

II. $\quad \sum \mathrm{XY}=\mathrm{a} \sum \mathrm{X}+\mathrm{b} \sum \mathrm{X} 2$

Keterangan: $Y^{\prime}=$ Tren

$\mathrm{X}=$ Nilai independen variabel dalam analisis tren adalah waktu (tahun)

$\mathrm{Y}=$ Jumlah penjualan

$\mathrm{N}=$ Jumlah data $\mathrm{a}$,

$\mathrm{b}=$ Konstanta Karena $\sum \mathrm{X}=0$ (tahun di tengah $\left.=0\right)$, maka persamaan di atas menjadi: $\sum \mathrm{Y}$

$\mathrm{Na} \quad \mathrm{a}=\sum \mathrm{Y} / \mathrm{N}$

$N \sum \mathrm{XY} \quad=\mathrm{b} \sum \mathrm{X} 2 \quad \mathrm{~b}=\sum \mathrm{XY} / \sum \mathrm{X} 2$

1. Perhitungan hasil peramalan

$Y^{\prime}=a+b X$ 


\subsection{Flowchart Metode Least Square}

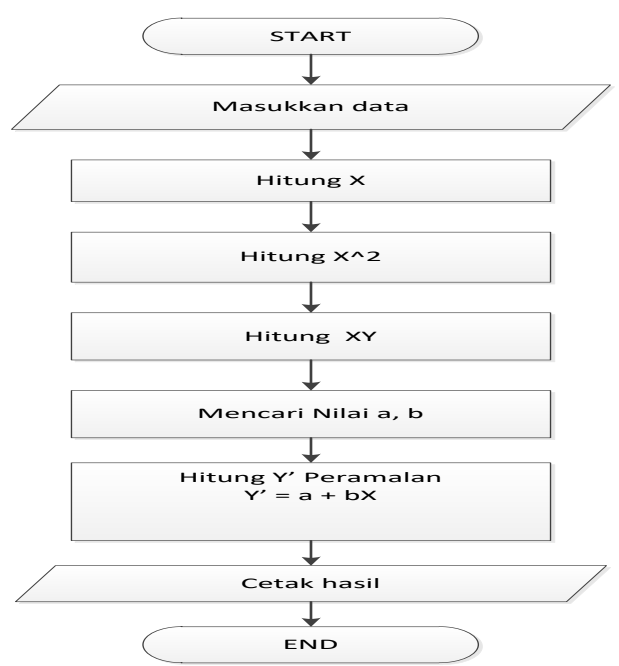

Gambar 2.2 Flowchart Metode

Penjelasan :

Pada Gambar 2.1 yaitu langkah perhitungan metode least square, pertama mulai dan memasukkan data, kemudian dilanjutkan mengitung nilai keseimbangan (x) selanjutnya menghitung nilai $\mathrm{X}^{\wedge} 2$, dilanjut hitung lia XY, berikutnya mencari nialai a dan $b$, dan kemudian menghtung nilai peramalan ( $\left.Y^{\prime}\right)$ selanjutnya proses cetak dan selesai.

\section{METODE PENELITIAN}

Untuk memperoleh suatu kesimpulan dari hasil pengumpulan data maka dilakukan analisis terhadap semua data yang terkumpul dan metode yang digunakan sesuai kebutuhan. untuk melakukan analisis yang di perlukan sebagai berikut:

\subsection{Sistem yang sudah ada}

Pada Doni Sport Malang segala proses transaksi dan arsip dilakukan manual sehingga tidak efisien. Di harapkan dengan adanya sistem prediksi ini dapat membantu proses perhitungan Penjualan pada bulan berikutnya.

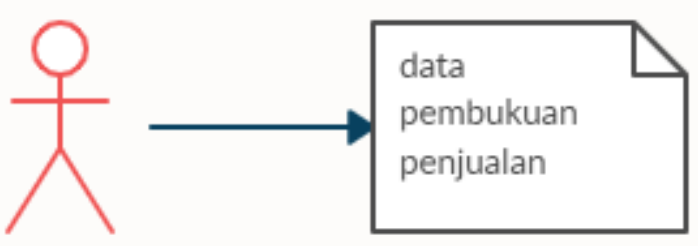

pemlik

Gambar 3.1.1 Blok Diagram Pada Sistem Yang Sudah ada

Gambar 3.1.1 Pemilik melakukan inputa data secara manual.

\subsection{Sistem yang Akan dibuat}

Dibuatkan sistem yang baru pada Doni Sport Malang agar segala proses transaksi penjualannya yang masih menggunakan cara manual, dengan adanya sistem yang baru agar dapat efisien.

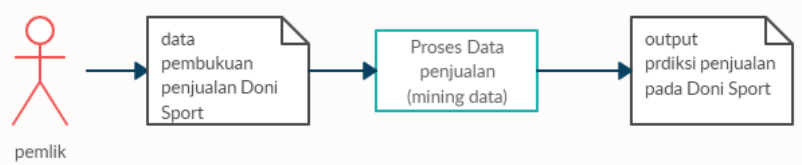

Gambar 3.1.2 Blok Diagram Sistem yang baru

Gambar 3.1.2 Pemilik Melakukan inputan data kedalam sebuah system data mining prediksi penjualan, kemudian setelah dilakukan mining data maka hasil akan dikeluarkan.

\subsection{Kebutuhan Sistem}

Kebutuhan fungsional merupakan kebutuhan atau fungsi yang harus di miliki oleh sebuah sistem. Dengan di deskripsikan kebutuhan fungsional ini, maka suatu sistem memiliki sebuah target yang harus dipenuhi. Berikut beberapa kebutuhan fungsional sistem yang akan dibuat:

a. Sistem Dapat Menampilkan Data Penjualan

b. System Dapat menyimpan Data Penjualan

c. Sistem Dapat Menghitung Data Penjualan

d. Sistem Dapat Merekap Data Penjualan

e. Sistem dapat Menampilkan Hasil Prediksi Penjualan

Kebutuhan nonfungsional adalah sebuah tahapan seorang pembangun perangkat lunak menganalisis sumber daya yang akan menggunakan perangkat lunak yang di bangun, sehingga dapat di tentukan kompabilitas aplikasi terhadap sumber daya yang ada. Berikut beberapa kebutuhan non-fungsional sistem yang akan dibuat :

a. Interface yang digunakan memiliki desain yang user friendly agar memudahkan admin dalam penggunaan.

b. Bahasa program yang digunakan adalah bahasa Indonesia

c. Availability aplikasi tersedia 24 jam sehingga dapat di akses kapan saja.

\subsection{Desain Flowchart Sistem}

Flowchart adalah adalah suatu bagan dengan simbol-simbol tertentu yang menggambarkan urutan proses secara detail dan hubungan antara suatu proses (instruksi) dengan proses lainnya dalam suatu program. 


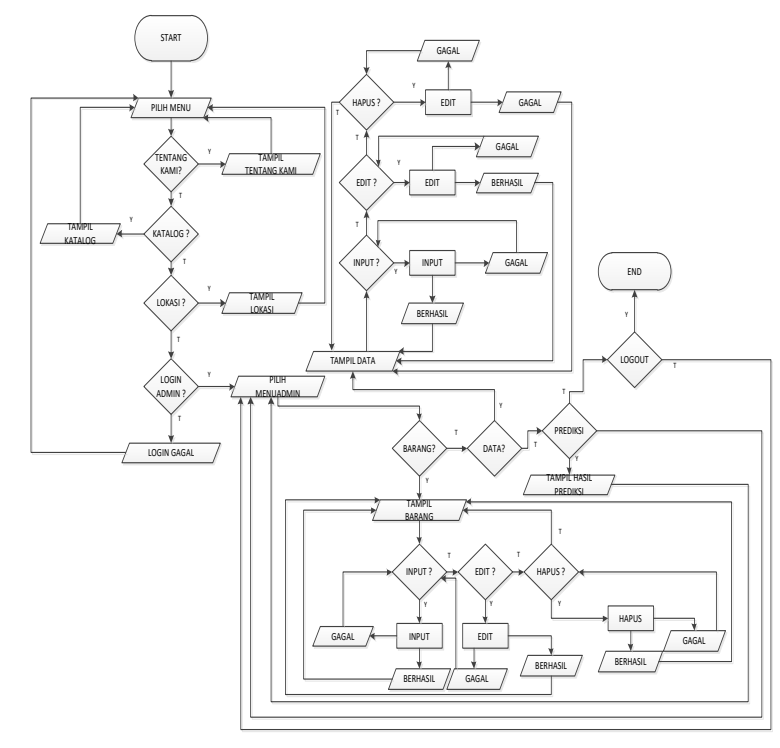

Gambar 3.1 Flowchart sistem

Flowchart system diatas adalah langkah system pada web doni sport malang, mulai dari pilihan menu pada home hingga login dan peramalan. Pertama memulai, kemudian memilih menu home pada web Doni Sport malang, jika memilih tentang kami maka ditampilkan tentang doni sport malang. Jika tidak maka lanjut apakah memilih katalog jika iya mka ditampilkan beragai macam katalog penjualan dni sport malang. Jika tidak lanjut pada menu lokasi, apakah benar lokasi jika iya maka ditampilkan google map dari lokasi doni sport malang, dan jika tidak maka selanjutnya pada menu login, apakah benar login ji kaa iya maka pilih menu admin, jika tidak apakah menu data barang, jika iya maka ditampilkan data barang dan ada pilihan lagi apakah edit jika ya maka data diedit jika tidak apakah hapus data, jika yam aka hapus data. dan terakhir pada pilihan apakah peramalan jika iya maka tampilkan hasil peramalan dan selesai.

\subsection{Desain DFD Level 0}

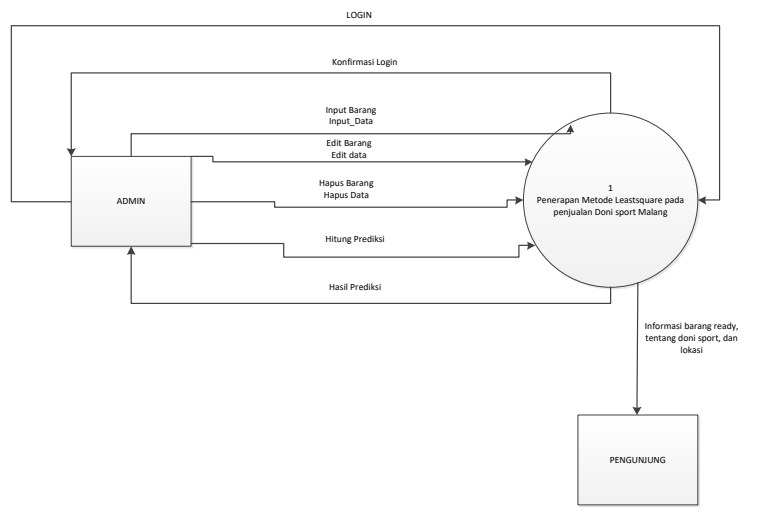

Gambar 3.2 dfd level 0
Gambar 3.5 meperlihatkan aliran data yang digunakan pada sistem ini pertama-tama admin akan melakukan login, kemudian konfirmasi login, setelah itu input data, edit data jika ada perubahan data, dan hapus data bila ada data yang tidak di perlukan, data yang sudah di inputkan akan di proses untuk memprediksi.

\subsection{Desain DFD Level 1}

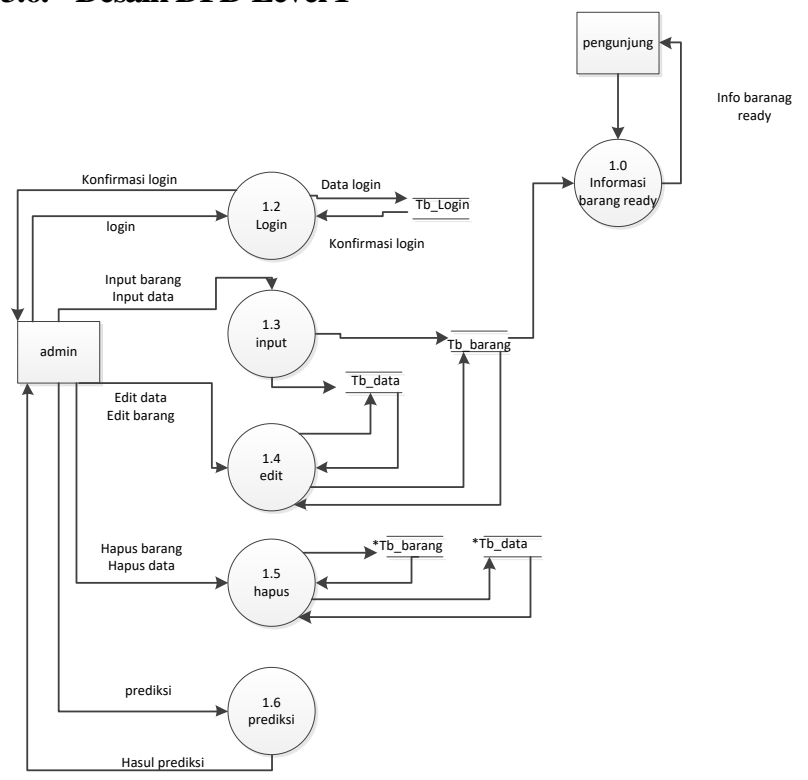

Gambar 3.3 DFD level 1

Pada Gambar 3.6 memperlihatkan aliran data yang digunakan pada sistem ini pertama-tama admin akan melakukan admin input data kedalam database kemudian database mengkonfirmasi data yg sudah masuk,admin edit data di proses kemudian di simpan di database, admin hapus data yang ada di dalam database, kemudian pilih barang yang akan di prediksi, barang di proses untuk memprediksi hasil penjualan ke depan nya.

\section{HASIL DAN PEMBAHASAN}

Black box testing adalah pengujian yang dilakukan hanya mengamati hasil eksekusi melalui data uji dan memeriksa fungsional dari perangkat lunak.

\subsection{Pengujian Black Box pada menu home}

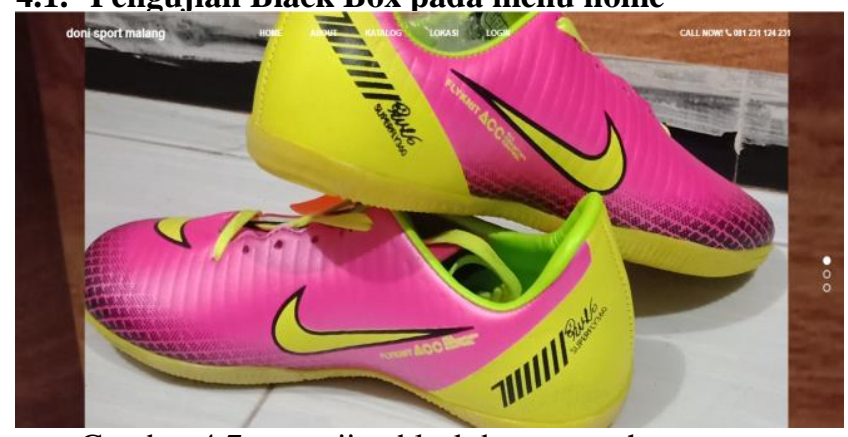

Gambar 4.7 pengujian black box menu home 
Pada gambar 4.7 kursor diarahan pada menu home dan dilakukan klik kemudia akan muncul gambar dari sepatu yang tampil.

\subsection{Pengujian Black Box pada menu about}

\section{DONI SPORT MALANG}

Doni Sport Malang berdiri pada tahun 2011 merupakan toko yang menyediakan bertagail macam kebutuhan yang bethubungan dengan alat olah raga. khususnya sepatu futsal dan sepatu sepak bola...... melayani pemesanan jersey team futsal dan sepak bolą, melayani reseler juga bagii yang mau memuka toko ofi daerah seluruh indonesia

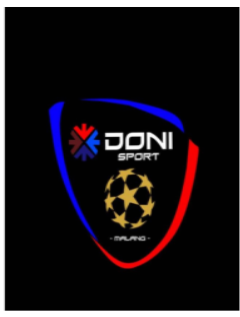

Gambar 4.8 pengujian black box menu about

Pada gambar 4.8 kursor diarahkan pada menu about dan di klik kemudian akan muncul pengenalan tentang doni sport malang.

\subsection{Pengujian Black Box pada menu katalog DATA BARANG}
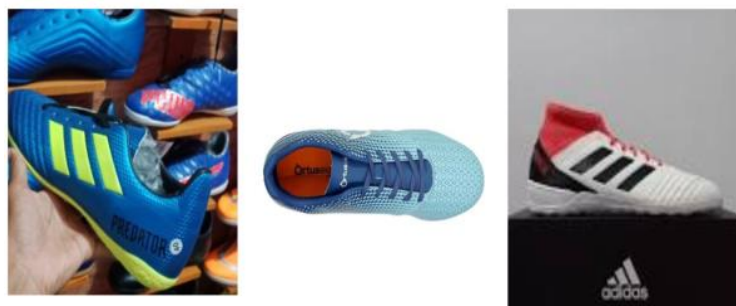

Gambar 4.9 pengujian black box menu katalog

Gambar 4.9 kursor diarahkan pada menu katalog dan dilakukan klik maka akan tampil barang yang rady pada toko Doni Sport Malang.

\subsection{Pengujian Black Box pada lokasi}

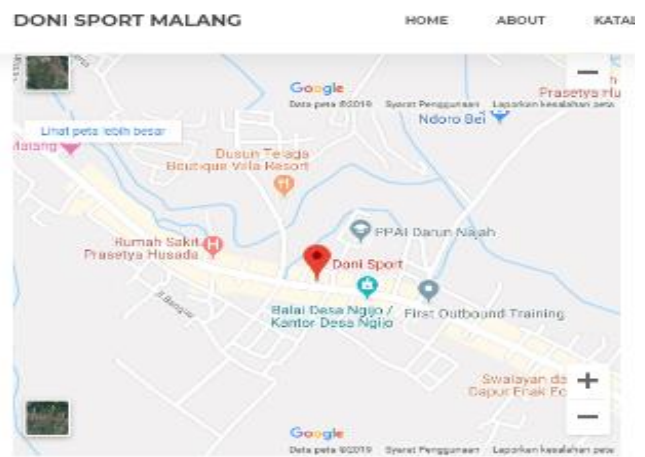

Gambar 4.10 pengujian black box pada lokasi

Pada gambar 4.10 Kursor tidak diarahkan pada petunjuk dan diklik pada bagian peta. Sistem tidak akan mengarahkan pada rute perjalan, tetapi akan menampilkan peta ke zoom.

\subsection{Pengujian Black Box pada lokasi}

Gambar 4.11 pengujian black box pada lokasi

Pada gambar 4.11 Kursor diarahkan pada petunjuk yang ada pada peta lalu klik. Sistem akan mengarahkan akan mengarahkan pada google map.

\subsection{Pengujian Black Box pada Login}

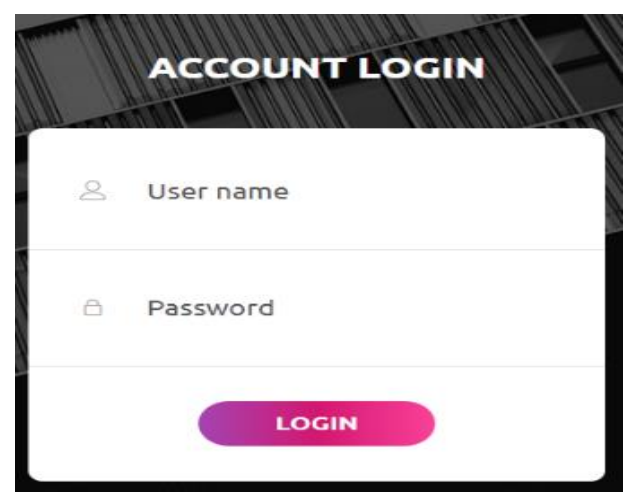

Gambar 4.12 pengujian black box pada login

Pada gambar 4.12 Login (user name dan password di kosongkan) Sistem tidak akan memberikan akses login pada home admin dan terdapat tanda (!) pada username dan password.

\subsection{Pengujian Black Box pada Login}

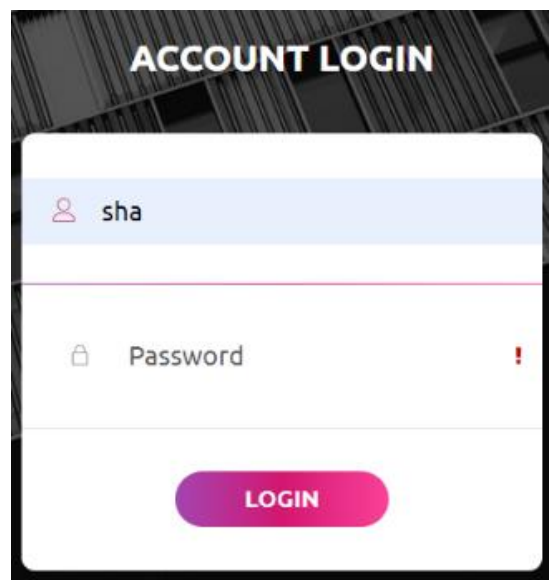

Gambar 4.13 pengujian black box pada login 
Pada gambar 4.13 Login (didisi pada username saja, password kosong) Sistem tidak akan memberikan akses login pada home admin dan terdapat tanda (!) pada password

\subsection{Pengujian Black Box pada Login}

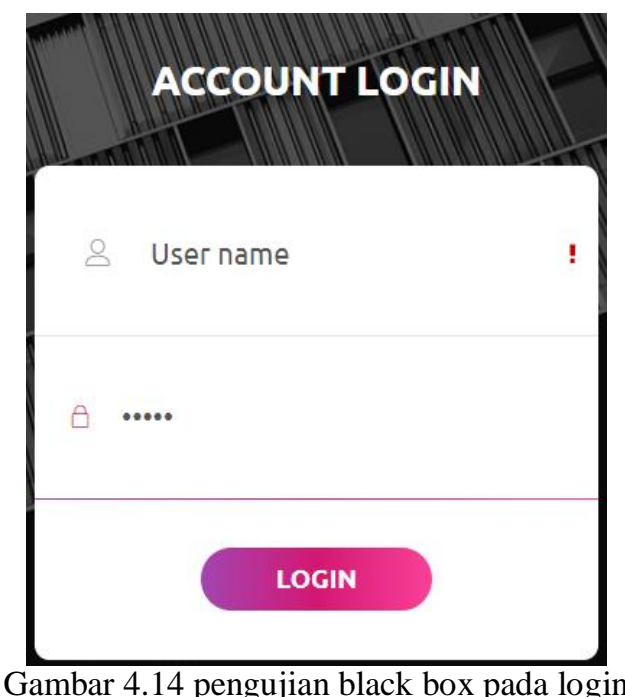

Pada gambar 4.14 Login (didisi pada password saja, username kosong) Sistem tidak akan memberikan akses login pada home admin dan terdapat tanda! pada username.

\subsection{Pengujian Black Box pada Login}

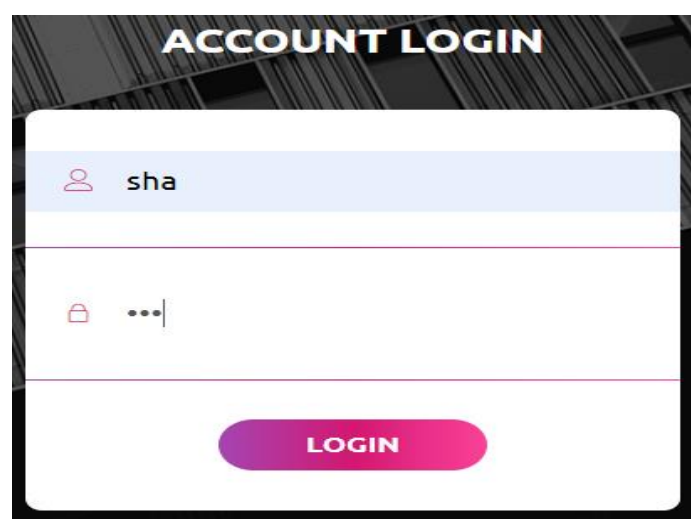

Gambar 4.15 pengujian black box pada login

Pada gambar 4.15 Login (username dan password diisi benar) System akan memberikan akses pada halaman admin.

\subsection{Pengujian Black Box pada input data}

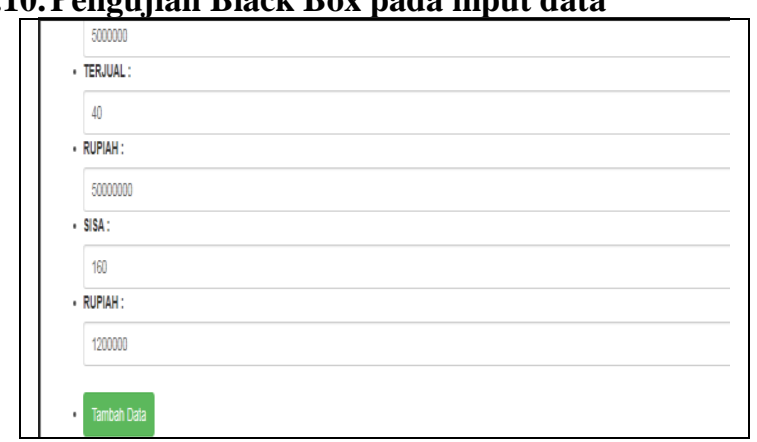

Gambar 4.16 pengujian black box pada input data

Pada gambar 4.16 isi kolom inputan dan klik pada tambah data, hasilnya data berhasil d masukkan.

\subsection{Pengujian Black Box pada hapus data}

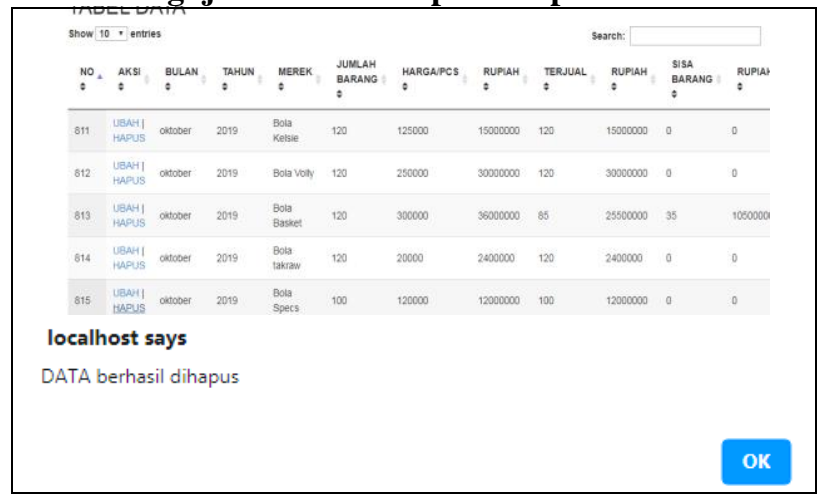

Gambar 4.17 pengujian black box pada input data

Pada gambar 4.17 klik pada hapus, hasilnya data berhasil dihapus

\subsection{Pengujian Black Box pada ubah data}

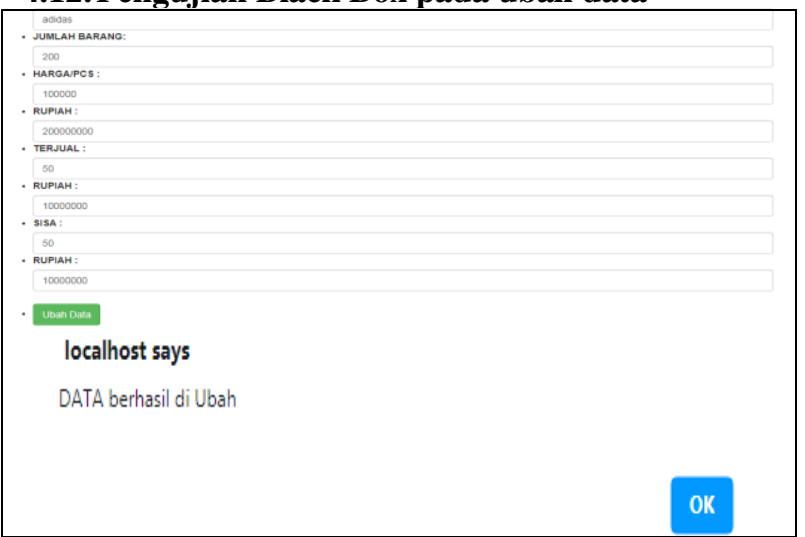

Gambar 4.18 pengujian black box pada ubah data

Pada gambar 4.18 klik padaubah, dan ganti field yang diubah hasilnya data berhasil diubah 


\subsection{Pengujian Black Box pada prediksi}

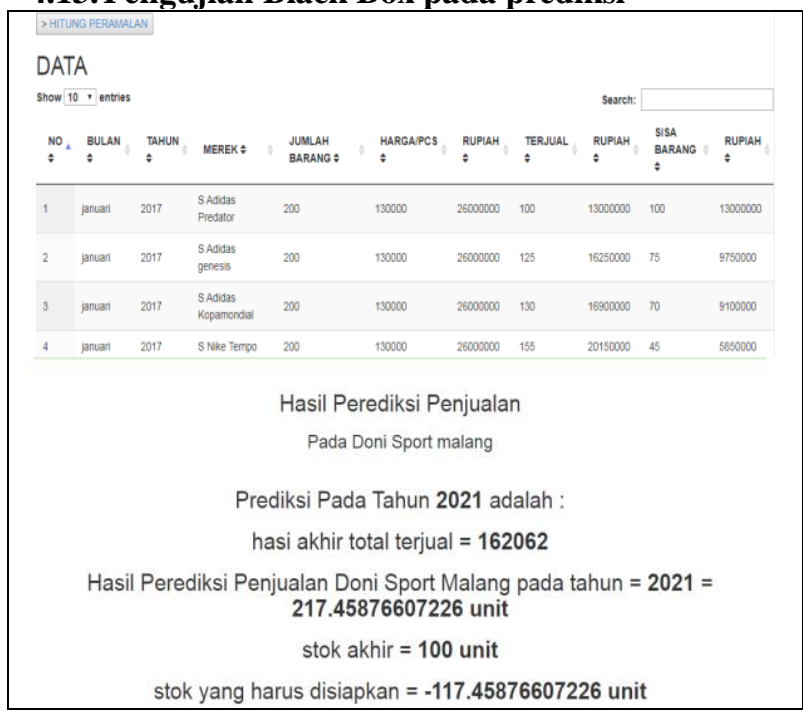

Gambar 4.19 pengujian black box pada ubah data

Pada gambar 4.19 klik pada menu prediksi , dan kemusian klik pada hitung peramalan, maka sistem akan memunculkan hasil dari perhitungan peramalan tersebut.

Tabel 4.1 pengujian black box

\begin{tabular}{|c|l|c|c|}
\hline \multirow{2}{*}{ No } & \multicolumn{2}{|c|}{ Scenario Pengujian } & \multicolumn{2}{|c|}{ Kesimpulan } \\
\cline { 3 - 4 } & berhasil & Tidak \\
\hline 1 & $\begin{array}{l}\text { Pengujian Black Box pada } \\
\text { menu home }\end{array}$ & $\checkmark$ & \\
\hline 2 & $\begin{array}{l}\text { Pengujian Black Box pada } \\
\text { menu about }\end{array}$ & $\checkmark$ & \\
\hline 3 & $\begin{array}{l}\text { Pengujian Black Box pada } \\
\text { menu katalog }\end{array}$ & $\checkmark$ & \\
\hline 4 & $\begin{array}{l}\text { Pengujian Black Box pada } \\
\text { lokasi }\end{array}$ & $\checkmark$ & \\
\hline 5 & $\begin{array}{l}\text { Pengujian Black Box pada } \\
\text { Login }\end{array}$ & $\checkmark$ & \\
\hline 6 & $\begin{array}{l}\text { Pengujian Black Box pada } \\
\text { input data }\end{array}$ & $\checkmark$ & \\
\hline 7 & $\begin{array}{l}\text { Pengujian Black Box pada } \\
\text { hapus data }\end{array}$ & $\checkmark$ & \\
\hline 8 & $\begin{array}{l}\text { Pengujian Black Box pada } \\
\text { ubah data }\end{array}$ & $\checkmark$ & \\
\hline 9 & $\begin{array}{l}\checkmark \quad \text { Pengujian Black } \\
\text { Box pada prediksi }\end{array}$ & $\checkmark$ & \\
\hline
\end{tabular}

Berdasarkan Pengujian Black Box diatas semua berfungsi sesuai perancangan yang diinginkan.

\subsection{Pengujian Metode Least square}

Tabel 4.3 Pengujian perhitungan metode Least Square Pada Stok Sepatu Adidas Terminator pada januari 2018-desember 2018.

\begin{tabular}{|l|c|c|c|c|}
\hline \multicolumn{1}{|c|}{ Bulan } & $\begin{array}{c}\text { Penjualan } \\
(\mathbf{Y})\end{array}$ & $\mathbf{X}$ & $\mathbf{X Y}$ & $\mathbf{X}^{\wedge} \mathbf{2}$ \\
\hline Januari & 100 & -6 & -600 & 36 \\
\hline Februari & 120 & -5 & -600 & 25 \\
\hline Maret & 125 & -4 & -500 & 16 \\
\hline April & 115 & -3 & -345 & 9 \\
\hline Mei & 105 & -2 & -110 & 4 \\
\hline Juni & 115 & -1 & -115 & 1 \\
\hline Juli & 126 & 1 & 126 & 1 \\
\hline Agustus & 118 & 2 & 236 & 4 \\
\hline September & 158 & 3 & 474 & 9 \\
\hline Oktober & 145 & 4 & 580 & 16 \\
\hline November & 120 & 5 & 600 & 25 \\
\hline Desember & 117 & 6 & 702 & 36 \\
\hline jumlah & 1464 & 0 & 348 & 182 \\
\hline
\end{tabular}

Untuk mencari nilai a dan b adalah sebagai berikut : $\mathrm{a}=1464 / 12=122$

$$
\mathrm{b}=348 / 182=1.912088
$$

Persamaan garis liniernya adalah :

$\mathrm{Y}=122+(1.91208 * \mathrm{X})$

Dengan menggunakan persamaan tersebut, dapat diramalkan penjualan pada tahun 2018 januari adalah

Untuk tahun 2018 januari nilai $\mathrm{X}$ adalah 12

$\mathrm{Y}=122+(1.91208 * 12)$ Sehingga: $\mathrm{Y}=122+$ $(1.91208 * 12)=144.9451$

Selisih jumlah terjual data asli Januari 2018 dan prediksi yaitu

Data asli januari $2018=125$

Data prediksi januari $2018=144.9451$ dibulatkan menjadi 145 unit

Selisih $=$ data prediksi - data asli

Selisih $=145-125=20$ unit.

\section{KESIMPULAN DAN SARAN}

\subsection{Kesimpulan}

Berdasarkan implementasi dan pengujian yang dilakukan dapat diambil kesimpulan bahwa :

1. Dengan pengujian Black Box. Kita dapat mengetahui hasil eksekusi melalui data uji dan memeriksa fungsional dari perangkat lunak, Pengujian diatas mendapatkan hasil yang sesuai dengan perancangan sistem bahwa fungsional sistem bekerja dengan baik.

2. Berdasarkan Pengujian yang dilakukan pada sistem prediksi data penjualan Doni Sport Malang menggunakan Metode Least Square didapatkan hasil prediksi pada Tahun 2020 sebesar 219 Unit.

3. Berdasarkan pengujian data penjulan sepatu Adidas Predator pada januari-desember 2017 mendapatkan hasil 145unit dan memiliki selisih 20unit dari data asli januari 2018. 


\subsection{Saran}

Dari beberapa kesimpulan yang telah diambil, maka dapat dikemukakan saran-saran yang akan sangat membantu untuk pengembangan perangkat lunak ini selanjutnya adalah sebagai berikut:

1. Pada penelitian tentang penerapan metode Least square untuk memprediksi hasil penjualan Pada Doni Sport Malang dapat dikembangkan dengan metode lain yaitu dengan metode moving average, Exponential Smoothing, dan Metode Naïve Bayes.

2. Pada saat melakukan sebuah cooding dan mengalami kesulitan yang tidak kunjung menemukan solusi, lebih baik meminta antuan kepada teman yang mungkin dapat membantu memecahkan masaah.

\section{DAFTAR PUSTAKA}

[1] Rahmawati (2013). Forcasting Penjualan Sepeda Motor Kawasaki Pada PT. Sumber Buana Motor Yogyakarta. Sistem Peramalan Jumlah Penjualan.

[2] Natalia (2014). ANALISIS PERAMALAN PENJUALAN DAN PENGENDALIAN PERSEDIAAN PADA PT.BENTORO ADISANDI. Analisis Peramalan Penjualan.

[3] Iskandar (2016). ANALISIS PERAMALAN PENJUALAN PRODUK

[4] Firnando dkk (2018) ANALISIS PERAMALAN PENJUALAN BUNCIS SUPER. 